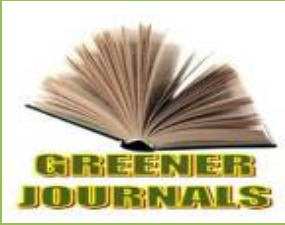

\title{
Phosphate Sorption Capacity, Bonding Energy and Buffering Mechanisms of Wetland Soils in Akwa Ibom State, Nigeria
}

\section{*Akpan US and Nkanga NA}

\author{
Department of Soil Science and Land Resources Management University of Uyo, Akwalbom \\ State, Nigeria
}

\section{ARTICLE INFO}

\section{ABSTRACT}

Article No.: 040517047

DOI: 10.15580/GJAS.2017.3.040517047

Submitted: 05/04/2017

Accepted: 08/04/2017

Published: 04/05/2017

${ }^{*}$ Corresponding Author

Akpan US

E-mail: udyakpa2k2@yahoo.com Phone: 08023783311

\section{Keywords:}

sorption capacity, bonding energy

and buffering capacity, wetland soils of Akwa lbom State
Phosphate sorption capacity, bonding energy and buffering capacity of wetland soils in Akwa Ibom State, Nigeria were assessed for effective and sustainable soil management. Three wetland types (inland depression, river floodplain and coastal swamp) were selected for the study. In each wetland type, three locations were selected (9 locations) and in each location, soil samples were collected from 3 points at the depth of $0-30 \mathrm{~cm}$ and bulked to form composite samples using soil auger and taken to the laboratory for analysis. In the laboratory, a solution containing $0,20,40$ and $80 \mathrm{ml}$ prepared from $6.15 \mathrm{~g}$ of $\mathrm{KH}_{2} \mathrm{PO}_{4}$ (Potassium hydrogen phosphate) in $1500 \mathrm{ml}$ of distilled water and make up to two (2) litres with distilled water was used for the study. $2.5 \mathrm{~g}$ of soil samples were weighed into a $50 \mathrm{ml}$ plastic cup and $2.5 \mathrm{ml}$ of each of the 4 sorption treatments solution were added to each of the soil in the cups and mixed thoroughly for effective mixing of $P$ solution with the soil. The set ups were covered and incubated for 7 days. The treated soil samples were watered with deionized water once to keep the sample moist throughout the period of incubation. On the 7th day, $P$ in each of the treated soil samples and the leachate were extracted using Bray-P-1 extractant. The $P$ in the extract was determined using Murphy and Riley method. The $P$ extracted from the soil samples were considered to be $P$ adsorbed while $P$ in the leachate samples were considered to be $P$ in solution. Langmuir equation was used to estimate $P$ adsorption capacity, bonding energy and $P$ buffering capacity of the soils. The results showed that floodplain soils had the highest mean phosphate adsorption capacity $(0.50$ $\left.\mathrm{mgkg}^{-1}\right)$, followed by soils of inland depression $\left(0.32 \mathrm{mgkg}^{-1}\right)$ while coastal swamp soils had the least $\left(0.09 \mathrm{mgkg}^{-1}\right)$. The trend was as follow: floodplain soils > soils of inland depression $>$ coastal swamp soils. Coastal swamp soils had the highest bonding energy $\left(0.54 \mathrm{Lmg}^{-1}\right)$, followed by floodplain soils $\left(0.27 \mathrm{Lmg}^{-1}\right)$ while soils of inland depression had the least $(0.07$ $\mathrm{Lmg}^{-1}$ ). The trend was as follow: coastal swamp soils $>$ floodplain soils $>$ soils of inland depression. Floodplain soils had the highest maximum buffering capacity $(0.047)$, followed by coastal swamp soil $(0.042)$ while soils of inland depression had the least $(0.018)$. The trend was as follow: Floodplain soils > coastal swamp soils > soils of inland depression. Hence, the three wetland soil types were not the same in $\mathbf{P}$ sorption capacity, bonding energy and buffering capacity. 


\section{INTRODUCTION}

Phosphate sorption is either the adsorption or movement of insoluble inorganic $\mathrm{P}$ from soil solution to soil mineral solid surfaces, where it accumulates without penetrating the soil structure and absorption, where the soluble inorganic $P$ penetrates into the soil structure. The release of the adsorbed inorganic $P$ from the mineral soil solid into soil solution is described as desorption (Rhue and Harries, 1999). The balance between $P$ adsorption and desorption maintains the equilibrium of $P$ between the soil solution and the soil solid and is described as phosphorus buffering capacity. Hence, phosphorus sorption index of soil is the capacity of soil to remove soluble $\mathrm{P}$ ( $\mathrm{P}$ in solution) through physical, chemical and biological processes, and retain it in a form that is not easily released under normal environmental conditions (Reddy et al., 1999).

Phosphate sorption capacity of wetland soils are influenced or regulated by various physicochemical properties of soil such as clay, $\mathrm{Fe}, \mathrm{Al}$, organic matter and soil $\mathrm{pH}$. Soil organic $\mathrm{P}$ and inorganic $\mathrm{P}$ are stabilized by association with mineral components of the soil. Negatively charged phosphorus compounds attach themselves to mineral components such as aluminosilicate minerals and hydrous $\mathrm{Fe}$ or $\mathrm{Al}$ oxides (Solomon and Lehmann, 2000; Turner et al., 2005). The $\mathrm{P}$ reactivity with $\mathrm{Fe} / \mathrm{Al}$ oxyhydroxides turns large proportions of soil $\mathrm{P}$ into unavailable forms (Arai and Livi, 2013; Solomon et al., 2002). Different forms of Fe/Al oxides have varying $P$ adsorption capacities and many researchers reported that amorphous $\mathrm{Fe} / \mathrm{Al}$ oxides carried the majority of $\mathrm{P}$ in soils, despite higher abundance of crystalline Fe oxides (Arai and Livi, 2013; Arai et al., 2005; Rick and Arai, 2011). Additionally, finersized soil fractions (clay) were found to be enriched in highly active and easily mineralized organic $P$ than larger particles (Rubæk et al., 1999). According to CadeMenun, (2005) organic $P$ forms increased with decreasing particle size and the smaller the size of soil particles the more reactive and have higher P-retaining capacity due to increased surface area than larger soil particles.

Several models have been developed to quantitatively described the sorption isotherm and relate the $\mathrm{P}$ concentration in soil solution to that retained by the solid phase. Sposito, (1989) reported that Langmuir isotherm can describe both adsorption and precipitation capacity of $P$ in the soil. The Langmuir equation allows the estimation of an adsorption maximum and bonding energy constant. The underlying assumption is that adsorption accrues in a monolayer on the soil surface. The adsorption maximum derived from the Langmuir equation is useful parameter for estimating $P$ adsorption capacity and comparing different soils (Borling, 2003). Ho et al. (2002) stated that at low substrate concentration, the Langmuir isotherm effectively reduce to linear isotherm and thus obey the Henry's law. On the other hand, at high sorbet concentration, it predicts a constant monolayer-adsorption capacity. After fitting the adsorption data to Langmuir model, "b" and "KL" can be obtained. The reciprocal of slop "b", called maximum adsorption (b) can be used to estimate the amount of fertilizer to be added to an unfertilized soil (Rehman et al., 2005). The high value of "b" is an indication that $P$ has been retained by the soil through sorption reaction while low value indicate that $P$ remain in solution where it is available for plant or transport. The $\mathrm{KL}$ is obtained by dividing "the value of reciprocal of the $\mathrm{Y}$ - intercept", i.e. $\{1 / \mathrm{KLb}\}$ with the value of adsorption maximum (the unit of the $K L$ is $L \mathrm{mg}-1$ ). The affinity coefficient (bonding energy constant) (KL) indicated comparatively how easily the added $P$ is adsorbed on or release from the adsorbing surface (Rehman et al., 2005). Mehandi and Taylor (1988) reported that smaller KL values indicated that more amount of adsorbed $\mathrm{P}$ will be converted to non-exchangeable form either by the formation of crystalline $\mathrm{P}$ or by occultation through $\mathrm{P}$ ions (less strongly retained). According to the Del-Bubba et al. (2003), KL is a measure of affinity of the adsorbate for the adsorbent. Anderson and Wu (2001) stated that a high $\mathrm{KL}$ value is an indication of the high clay contents of respective soil and it estimates the strength of bonding to clay minerals in the soil (strongly retained). Maximum buffering capacity (MBC) of a soil is a product of the Langmuir bonding energy constant (KL) and adsorption maximum (b). It is a capacity factor, which measures the ability of the soil to replenish $P$ ion to soil solution as they tend to be depleted (Rehman et al., 2005). Low buffering capacity values indicate that the soil has limited ability to tie up applied $P$ (less adsorption sites) and more $\mathrm{P}$ is available to plant (more $\mathrm{P}$ in solution).Conversely, high buffering capacity values indicate soil types that have the ability to quickly bind up (more adsorption sites) $\mathrm{P}$ and make it unavailable to plant (les $\mathrm{P}$ in solution).

Information on the phosphate sorption index, bonding energy and $\mathrm{P}$ buffering capacity of wetland soils in Akwa lbom State is grossly inadequate to guide $P$ fertilizer recommendation and application. Therefore, this study was conducted to establish phosphate sorption index, bonding energy and buffering capacity of wetland soils in the state for effective and sustainable land use planning using Langmuir isotherm.

\section{MATERIALS AND METHODS}

\section{The study area}

The study was conducted in Akwa Ibom State, SouthSouth Nigeria. The state lie within latitudes $4^{\circ} 30^{\prime}$ and $5^{\circ} 30^{\prime} \mathrm{N}$ and longitudes $7^{\circ} 30^{\prime}$ and $8^{\circ} 20^{\prime} \mathrm{E}$. The climate is humid tropical with annual rainfall of about 2500 to 3000 $\mathrm{mm}$ with 1 to 3 dry months in the year. Mean annual temperature varies between 27 and $28^{\circ} \mathrm{C}$ with relative humidity of 75 to $80 \%$ (Petters et al., 1989). 


\section{Field Study}

Three wetland types were selected for the study. They were inland depression, river flood plains and coastal swamp. In each wetland type, three locations were selected (9 locations). In each location, soil samples were collected from 3 points at the depth of $0-30 \mathrm{~cm}$ and bulked to form composite samples using soil auger.

\section{Laboratory Study}

\section{Phosphate sorption}

Stock solution was prepared by dissolving $6.15 \mathrm{~g}$ of $\mathrm{KH}_{2}$ $\mathrm{PO}_{4}$ (Potassium hydrogen phosphate) in $1500 \mathrm{ml}$ of distilled water and make up to two (2) litres with distilled water. Three (3) sorption treatments were prepared by diluting 20,40 and $80 \mathrm{ml}$ of the stock solution to $100 \mathrm{ml}$. $2.5 \mathrm{~g}$ of soil samples were weighed into a $50 \mathrm{ml}$ plastic cup and $2.5 \mathrm{ml}$ of each of the 3 sorption treatments solution were added to each of the soil in the cups and mixed thoroughly for effective mixing of $P$ solution with the soil.. The set up were covered and incubated for 7 days. The treated soil samples were watered with deionized water once to keep the sample moist throughout the period of incubation (Ayodele and Agboola 1981). At the set day, (7 days), $P$ in each of the treated soil samples and the leachate were extracted using Bray-P-1 extractant. The $P$ in the extract was determined using Murphy and Riley method. The $P$ extracted from the soil samples were considered to be $P$ adsorbed while $P$ in the leachet samples were considered to be $P$ in solution.

Other analyses carried out were: Particle size was determined using the Bouyoucos hydrometer method as described by Udo et al. ( 2009 ). Soil pH was determined with a glass electrode $\mathrm{pH}$ meter in distilled water using 1:2.5 soil/water suspension as described by Udo et al. (2009). Organ carbon was determined by the wet oxidation method of Walkley and Black as modified by Nelson and Sommers (1982). ECEC was obtained by the summation of all exchangeable bases and total exchangeable acidity. Crystalline forms of $\mathrm{Fe}$ and $\mathrm{Al}$ oxides were extracted from the soil samples using the Dithionite Citrate Bicarbonate procedure while the amorphous form of $\mathrm{Fe}$ and $\mathrm{Al}$ was extracted using ammonium oxalate acidified at $\mathrm{pH}$ 5.7. The content of Fe and $\mathrm{Al}$ in extracts was determined by atomic absorption spectrophotometer (Mckeaque et al., 1971).

\section{RESULTS AND DISUSSION}

\section{Physicochemical properties of the study area}

\section{Soil Texture}

In river floodplain soils, the sand fraction varied from 51.0 to $89.40 \%$ with a mean of 69.40 . The silt fraction ranged from 5.0 to $17.0 \%$ with a mean of $11.40 \%$ and clay fraction varied from 6.00 to $32.0 \%$ with a mean of $19.20 \%$. In inland depression soils, the sand fraction varied from 67.0 to $93.0 \%$ with a mean of $82.17 \%$. The silt fraction ranged from 1.0 to $13.0 \%$ with a mean of $6.67 \%$ and clay fraction varied from 6.00 to $21.0 \%$ with a mean of $11.17 \%$. In coastal swamp soils, the sand fraction varied from 87.0 to $92.0 .0 \%$ with a mean of $90.27 \%$. The silt fraction ranged from 1 to $12.0 \%$ with a mean of 3.25 and clay fraction varied from 7.00 to $21.0 \%$ with a mean of $8.25 \%$. The mean sand fraction of coastal swamp (CS) soils $(90.27 \%)$ was significantly higher $(p<0.05)$ than that of river floodplain (FP) soils $(69.40 \%)$ but was not significantly different from that of inland depression (ID) soils (82.17\%) in the study area. The mean silt fraction of FP soils $(11.40 \%)$ was significantly higher $(P<0.05)$ than that of $C S$ soils $(3.25 \%)$ and ID $(6.67 \%)$ soils. The mean clay fraction of FP soils $(19.20 \%)$ was significantly higher $(P<0.05)$ than that of ID soils $(11.83 \%)$ and CS soils $(7.17 \%)$. The low silt content of the study area agrees with Akamigbo (1984) that soils of Southeastern Nigeria are low in silt as a result of the high degree and extent of weathering and leaching they have undergone.

Table 1: Min., Max and mean of selected soil properties in the study area

\begin{tabular}{|c|c|c|c|c|c|c|c|c|c|c|}
\hline & $\begin{array}{l}\text { Sand } \\
(\%)\end{array}$ & $\begin{array}{l}\text { Silt } \\
(\%)\end{array}$ & $\begin{array}{l}\text { Clay } \\
(\%)\end{array}$ & $\begin{array}{r}\mathrm{pH} \\
\left(\mathrm{H}_{2} \mathrm{O}\right)\end{array}$ & $\begin{array}{l}\mathrm{OM} \\
(\%)\end{array}$ & $\begin{array}{l}\text { ECEC } \\
(\mathrm{cmol} / \mathrm{kg})\end{array}$ & $\begin{array}{l}\mathrm{Fe}_{d} \\
(\%)\end{array}$ & $\begin{array}{l}\mathrm{Feo} \\
(\%)\end{array}$ & $\begin{array}{l}\mathrm{Al}_{d} \\
(\%)\end{array}$ & $\begin{array}{l}\text { Alo } \\
(\%)\end{array}$ \\
\hline Min. & 51.0 & 5.00 & 6.00 & 5.5 & 0.24 & 14.68 & 0.10 & 0.13 & 0.03 & 0.02 \\
\hline Max. & 89.0 & 17.00 & 32.00 & 6.1 & 5.34 & 27.84 & 0.18 & 0.21 & 0.11 & 0.10 \\
\hline Mean & 69.40 & 11.40 & 19.20 & 5.8 & 3.04 & 18.86 & 0.13 & 0.14 & 0.06 & 0.06 \\
\hline \multicolumn{11}{|c|}{ Soils of inland depression } \\
\hline Min. & 67.00 & 1.00 & 6.00 & 6.2 & 0.95 & 7.36 & 0.10 & 0.13 & 0.03 & 0.03 \\
\hline Max. & 93.00 & 13.00 & 21.00 & 6.7 & 4.10 & 18.91 & 0.19 & 0.27 & 0.06 & 0.14 \\
\hline Mean & 82.17 & 6.67 & 11.17 & 6.3 & 2.48 & 11.95 & 0.13 & 0.16 & 0.06 & 0.07 \\
\hline \multicolumn{11}{|c|}{ Coastal swamp soils } \\
\hline Min. & 87.00 & 1.00 & 7.00 & 4.3 & 0.34 & 0.34 & 0.09 & 0.12 & 0.03 & 0.05 \\
\hline Max. & 92.00 & 12.00 & 21.00 & 6.6 & 5.64 & 5.64 & 0.17 & 0.27 & 0.09 & 0.15 \\
\hline Mean & 90.27 & 3.25 & 8.25 & 5.1 & 2.62 & 2.62 & 0.12 & 0.19 & 0.05 & 0.08 \\
\hline $\operatorname{LSD}(0.05)$ & 10.62 & 3.80 & 5.69 & 1.47 & 1.25 & 5.14 & 0.04 & 0.05 & 0.02 & 0.03 \\
\hline
\end{tabular}

$\mathrm{OM}=$ organic matter, ECEC $=$ effective cation echange capacity, $0=$ oxalate, $d=$ dithionate 


\section{Soil Reaction (Soil pH)}

In river floodplain soils, soil reaction ranged from 5.5 to 6.1 with a mean of 5.8 . In inland depression soils, the soil reaction varied from 6.2 to 6.7 with a mean of 6.3 . In coastal swamp soils, soil reaction varied from 4.3 to 6.6 with a mean of 5.1. The mean soil pH was moderately acid in soils of river floodplain, slightly acid in inland depression and strongly acid in coastal swamp soils (Enwezor et al., 1989). The trend of mean soil pH was as follows: $\mathrm{CS}<\mathrm{FP}<\mathrm{ID}$ soils. Statically, the mean soil $\mathrm{pH}$ values were not significantly different $(\mathrm{p}<0.05)$ from each other. Acidic reaction is characteristic of soils of Southeastern Nigeria because of the acidic nature of the parent rocks, coupled with the influence of the leached profile under high annual rainfall condition (Eshett et al., 1990). Coastal swamp soils had the lowest mean soil pH (5.8). This could be associated with the presence of pyrites in these soils, which oxidized to sulphuric acid on drying and aeration of the soils, thus lowering the $\mathrm{pH}$ values or increasing the acidity of the soils (Uniuyo Consults, 2001).

\section{Organic Matter}

In river floodplain soils, organic matter ranged from 0.24 to $5.34 \%$ with a mean of $3.0 \%$. In inland depression soils, OM varied from 0.95 to $4.10 \%$ with a mean of $2.5 \%$. In coastal swamp soils, OM varied from 0.34 to $5.64 \%$ with a mean of $2.6 \%$. Generally, mean organic matter was high in river floodplain, moderate in inland depression and coastal swamp soils. Statistically, there was no significant difference $(p<0.05)$ in organic matter among the three wetland types. The values obtained agree with Ojanuga et al., (2003), that the Cross River floodplains, part of which falls within Akwa Ibom State are characterized by levee soils, with moderate amount of organic matter ( $2 \%$ or more).

\section{Effective Cation Exchange Capacity (ECEC)}

In river floodplain soils, ECEC ranged from 14.68 to $27.84 \mathrm{cmol} / \mathrm{kg}$ with a mean of $18.86 \mathrm{cmol} / \mathrm{kg}$. In inland depression soils, ECEC varied from 7.36 to $18.91 \mathrm{cmol} / \mathrm{kg}$ with a mean of $11.95 \mathrm{cmol} / \mathrm{kg}$. In coastal swamp soils, ECEC varied from 7.84 to $24.50 \mathrm{cmol} / \mathrm{kg}$ with a mean of $13.83 \mathrm{cmol} / \mathrm{kg}$. The mean ECEC of FP soils $(18.86 \mathrm{cmol} / \mathrm{kg})$ was significantly higher $(P<0.05)$ than that of ID $(11.95 \mathrm{cmol} / \mathrm{kg})$ and CS (13.01) soils. Generally, mean ECEC was moderate in river floodplain and coastal swamp soils and low in land depression soils. The mean ECEC trend was as follows: ID soils < CS soils < FP soils. The moderate values of ECEC in FP and CS soils obtained could be attributed to the high organic matter in the soils. Nsor (2001) reported similar results in mangrove soils of Cross River State.

\section{Iron Oxides}

Dithionate $\mathrm{Fe}\left(\mathrm{Fe}_{\mathrm{d}}\right)$ of river floodplain soils, ranged from 0.10 to $0.18 \%$ with a mean of $0.13 \%$. In inland depression soils, varied from 0.10 to $0.19 \%$ with a mean of $0.13 \%$. In coastal swamp soils, dithionate $\mathrm{Fe}\left(\mathrm{Fe}_{\mathrm{d}}\right)$ varied from 0.09 to $0.17 \%$ with a mean of $0.12 \%$. Statistically, there was no significant difference $(P<$ 0.05 ) in means dithionate $\mathrm{Fe}$ among the wetland soil types under consideration.

In river floodplain soils, oxalate $\mathrm{Fe}\left(\mathrm{Fe}_{\mathrm{o}}\right)$ ranged from 0.13 to $0.21 \%$ with a mean of $0.14 \%$. In inland depression soils, oxalate $\mathrm{Fe}\left(\mathrm{Fe}_{\circ}\right)$ varied from 0.13 to $0.27 \%$ with a mean of $0.16 \%$. In coastal swamp soils, oxalate $\mathrm{Fe}\left(\mathrm{Fe}_{\circ}\right)$ varied from 0.12 to $0.27 \%$ with a mean of $0.19 \%$. The mean oxalate $\mathrm{Fe}$ of $\mathrm{CS}$ soils $(0.19 \%)$ was significantly $(P<0.05)$ higher than that of FP $(0.13 \%)$ soils but was not significantly different $(P<$ $0.05)$ from that of ID soils $(0.16 \%)$. The trend was as follows: CS soils > FP soils = ID soils. The mean values of $\mathrm{Fe}_{\circ}$ in the three wetland soils were greater than the means of $\mathrm{Fe}_{\mathrm{d}}$ indicating the prevalence of amorphous $\mathrm{Fe}$ in these soils than the crystalline Fe. This suggests that the soils are relatively less weathered with high proportion of ferrihyrite, a feature of most hydromorphic soils (Udo, 1980). The higher values of $\mathrm{Fe}_{o}$ also suggest that gleziation (major pedogenic process) is prevalence in the soil and induces the alteration, mobilization and fixation of iron following water movement (Khan et al., 1997). It has been reported that $P$ and metal sorptivity are higher with amorphous than crystalline oxides (Uzoho and Oti, 2005). This indicates that ion sorption was controlled by amorphous $\mathrm{Fe}$ rather than $\mathrm{Al}$ in these soils especially in inland depression and coastal swamp soils.

\section{Aluminium Oxides}

In river floodplain soils, dithionate $\mathrm{Al}(\mathrm{Al})$ ranged from 0.03 to $0.11 \%$ with a mean of $0.06 \%$. In inland depression soils, dithionate $\mathrm{Al}\left(\mathrm{Al}_{\mathrm{d}}\right)$ varied from 0.03 to $0.06 \%$ with a mean of $0.06 \%$. In coastal swamp soils, dithionate $\mathrm{Al}(\mathrm{Al}$ d) varied from 0.03 to $0.09 \%$ with a mean of $0.05 \%$.. Statistically, there was no significant difference $(P<0.05)$ in mean dithionate $A l$ among the three wetland soil types studied. In river floodplain soils, oxalate $\mathrm{Al}(\mathrm{Ald})$ ranged from 0.02 to $0.10 \%$ with a mean of $0.06 \%$. In inland depression soils, oxalate $\mathrm{Al}$ (Ald) varied from 0.03 to $0.14 \%$ with a mean of $0.07 \%$. In coastal swamp soils, oxalate $\mathrm{Al}\left(\mathrm{Al}_{\mathrm{d}}\right.$ ) varied from 0.05 to $0.15 \%$ with a mean of $0.08 \%$. Statistically, there was no significant difference $(P<0.05)$ in oxalate $A l$ mean among the three wetland soil types studied. This result is in tandem with the low mean Alo values $(0.02-0.09 \%)$ of some floodplain soils of Southeastern Nigeria (Ibia, 2005). The mean values of $A l_{o}$ in the three wetland soils were greater than the mean Ald indicating the prevalence of amorphous $\mathrm{Al}$ in these soils than the crystalline $\mathrm{Al}$ which confirms that the soils are relatively less weathered and more reactive. 


\section{Adsorption capacity of soils of the study area}

The adsorption capacity of soils of the study area is presented in Table 2.The result showed that floodplain soils had the highest mean maximum phosphate adsorption capacity $\left(60.3 \mathrm{mgkg}^{-1}\right)$, followed by soils of inland depression $\left(6.0 \mathrm{mgkg}^{-1}\right)$ while coastal swamp soils had the least $\left(2.6 \mathrm{mgkg}^{-1}\right)$. The trend was as follow: floodplain soils > soils of inland depression > coastal swamp soils. The high maximum adsorption capacity of river floodplain soils is an indication that floodplain soils had the highest $\mathrm{P}$ adsorption capacity (high adsorption sites) compared to that of inland depression and coastal swamp soils. This could be attributed to the high cation exchange capacity of river floodplain soils which is due to high finer soil particles (silt and clay fraction) with permanent charge surfaces, resulting in high adsorption sites compared to soils of inland depression and coastal swamp soils (Reddy and Delune, 2005). The low adsorption capacity of coastal swamp soil despite the significantly higher amorphous $\mathrm{Fe}$ and $\mathrm{Al}$ could be due to organic matter content in the soil which is not significantly different $(p<0.05)$ from that of the floodplain soil. This is because organic matter in the soil with $\mathrm{pH}<6.0$ decreases $\mathrm{P}$ - adsorption due to the following reasons. Either the organic acid produced by the mineralisation of organic matter compete for adsorption sites with $\mathrm{P}$ thereby reducing adsorption sites for $P$ or repuls phosphate or the combination of organic acid with $\mathrm{Fe}(\mathrm{Fe}-\mathrm{P})$ and $\mathrm{Al}(\mathrm{Al}-\mathrm{P})$ oxides reduces the $\mathrm{P}$ adsorption capacity of the oxides (Hunt et al., 2007).

Table 2: Langmuir constants and linear equation for phosphate adsorption in the study area

\begin{tabular}{|c|c|c|c|c|c|c|}
\hline Wetland type & $\begin{array}{l}\text { P added } \\
(\mathrm{mg} / \mathrm{l})\end{array}$ & Equation & $\mathrm{R}^{2}$ & $\begin{array}{l}\text { Maximum } \\
\text { Adsorption } \\
(1 / b)\end{array}$ & $\begin{array}{l}\text { Bonding } \\
\text { Energy } \\
(1 / \mathrm{kL} \\
1 / \mathrm{b}\end{array}$ & $\begin{array}{l}\text { Maximum } \\
\text { Buffering } \\
\text { Capacity } \\
\left(1 / \mathrm{KL}{ }^{*} 1 / \mathrm{b}\right)\end{array}$ \\
\hline \multirow{5}{*}{$\begin{array}{l}\text { Inland } \\
\text { depression }\end{array}$} & 0 & $\mathrm{C} / \mathrm{S}=44.52+0.06612 \mathrm{C}$ & 0.098 & 15.1 & 0.0015 & 0.023 \\
\hline & 20 & $C / S=53.89+0.1310 C$ & 0.43 & 7.6 & 0.0024 & 0.018 \\
\hline & 40 & $\mathrm{C} / \mathrm{S}=50.31+1.316 \mathrm{C}$ & 0.47 & 0.76 & 0.026 & 0.0198 \\
\hline & 80 & $C / S=100.6+1.7789 C$ & 0.036 & 0.56 & 0.018 & 0.0101 \\
\hline & Mean & & & 6.00 & 0.012 & 0.018 \\
\hline \multirow{5}{*}{$\begin{array}{l}\text { Floodplain } \\
\text { soils }\end{array}$} & 0 & $C / S=7.25+0.4039 C$ & 0.34 & 2.48 & 0.056 & 0.139 \\
\hline & 20 & $\mathrm{C} / \mathrm{S}=34.28-0.00513 \mathrm{C}$ & 0.000197 & 194.9 & 0.00022 & 0.043 \\
\hline & 40 & $\mathrm{C} / \mathrm{S}=31.28-0.02332 \mathrm{C}$ & 0.00097 & 42.88 & 0.00075 & 0.032 \\
\hline & 80 & $C / S=46.46-1.167 \mathrm{C}$ & 0.3188 & 0.86 & 0.025 & 0.022 \\
\hline & Mean & & & 60.3 & 0.020 & 0.059 \\
\hline Coastal swamp & 0 & $\mathrm{C} / \mathrm{S}=2.027+0.3198 \mathrm{C}$ & 0.79 & 3.13 & 0.16 & 0.501 \\
\hline \multirow[t]{4}{*}{ Soils } & 20 & $\mathrm{C} / \mathrm{S}=21.36+0.2833 \mathrm{C}$ & 0.28 & 3.53 & 0.013 & 0.046 \\
\hline & 40 & $\mathrm{C} / \mathrm{S}=42.09+0.3957 \mathrm{C}$ & 0.056 & 2.53 & 0.0094 & 0.024 \\
\hline & 80 & $\mathrm{C} / \mathrm{S}=59.98+0.7275 \mathrm{C}$ & 0.034 & 1.37 & 0.012 & 0.016 \\
\hline & Mean & & & 2.64 & 0.049 & 0.15 \\
\hline
\end{tabular}

\section{Bonding energy of soils of the study area}

The bonding energy coefficient of the study area which represents whether the added $P$ is being adsorbed loosely or tenaciously on soil surface is presented in Table 2. The result showed that coastal swamp soils had the highest bonding energy $\left(0.049 \mathrm{Lmg}^{-1}\right)$ (adsorbed $\mathrm{P}$ tenaciously), followed by floodplain soils $\left(0.020 \mathrm{Lmg}^{-1}\right)$ while soils of inland depression had the least $(0.012$ $\mathrm{Lmg}^{-1}$ )(adsorbed $\mathrm{P}$ loosely). The trend was as follow: coastal swamp soils $>$ floodplain soils $>$ soils of inland depression. This shows that phosphate ions are held more tenacious in coastal swamp soils, less tenacious in floodplain soils and loosely in soils of inland depression. The high bonding energy of the coastal swamp soil compared to others could be attributed to the high content of amorphous $\mathrm{Fe}$ and $\mathrm{Al}$ in the soil with specific adsorption of phosphate on the oxide surfaces. Oxides of Fe have variable charge. At hydroxylated or hydrated surfaces of $\mathrm{Fe}$ oxides, positive or negative charge is created by adsorption or desorption of $\mathrm{H}^{+}$or $\mathrm{OH}^{-}$ions, which is controlled by $\mathrm{H}^{+}$or $\mathrm{OH}^{-}$ion concentration in solution ( $\mathrm{pH}$ dependent). Sorption of $\mathrm{P}$ occurs through ligand exchange on variable charge surfaces by the exchange of $\mathrm{OH}^{-}$on the surfaces for phosphate ion. Sorption takes place at specific coordination sites $\left(\mathrm{OH}^{-}\right)$ on the oxides or hydroxides. There is a covalent bond between metal ion and phosphate ion. Specifically bound $P$ is more strongly surface - associated through covalent bonds formed by ligand exchange with the oxide surface $\mathrm{OH}^{-}$group while non-specifically bound $\mathrm{P}$ is weakly surface - associated due to electrostatic interaction ( Yuji and Sparks, 2001; Hunt et al., 2007).

\section{Maximum phosphate buffering capacity and buffering mechanisms of soils of the study area}

The maximum phosphate buffering capacity of soils of 
the study area is shown in Table 2. The result showed that coastal swamp soils had the highest maximum buffering capacity $(0.15)$, followed by floodplain soils (0.059) while soils of inland depression had the least (0.018). The trend was as follow: coastal swamp soils > floodplain soils > soils of inland depression. The high buffering capacity is an indication of less $P$ in solution (held more $P$ ) while low buffering capacity indicated more $\mathrm{P}$ in solution (held less $\mathrm{P}$ ). The high phosphate buffering capacity of coastal swamp soils compared to others could be due to specifically bound $P$ which is strongly surface- associated through ligand exchange (covalent bonding) and release $P$ from adsorption sites when $P$ in solution is reduced (Reddy et al., 1999). This shows that soils of inland depression with low buffering capacity have high potential to leach $\mathrm{P}$ from the soil to underground water.

\section{Correlation coefficient of maximum adsorption capacity with some soil properties}

The correlation coefficient of maximum adsorption capacity with selected soil properties in the study area is presented in Table 3 . The result showed that, in soils of inland depression, maximum adsorption capacity strongly and positively correlated with organic matter ( $r=$ 0.80 ), strongly and negatively correlated with amorphous $\mathrm{Fe}(r=-0.80)$ and strongly and positively correlated with crystalline Al.

Table 3: Correlation coefficient of maximum adsorption with selected soil properties in the study area

\begin{tabular}{llll}
\hline Soil property & \multicolumn{2}{c}{ Max Adsorption } \\
& Inland depression & Floodplain soils & Coastal swamp soils \\
\hline pH & 0.15 & 0.97 & 0.20 \\
Organic matter $(\%)$ & 0.80 & 0.52 & 0.69 \\
ECEC $(\mathrm{cmol} / \mathrm{kg})$ & 0.41 & -0.28 & -0.36 \\
Clay $(\%)$ & -0.45 & 0.04 & 0.23 \\
Feo $(\mathrm{mg} / \mathrm{kg})$ & -0.80 & $1.0^{\star *}$ & 0.34 \\
Fed $(\mathrm{mg} / \mathrm{kg})$ & -0.23 & 0.76 & 0.91 \\
Alo $(\mathrm{mg} / \mathrm{kg})$ & 0.40 & -0.53 & 0.93 \\
Ald $(\mathrm{mg} / \mathrm{kg})$ & 0.70 & 0.95 & -0.92 \\
\hline
\end{tabular}

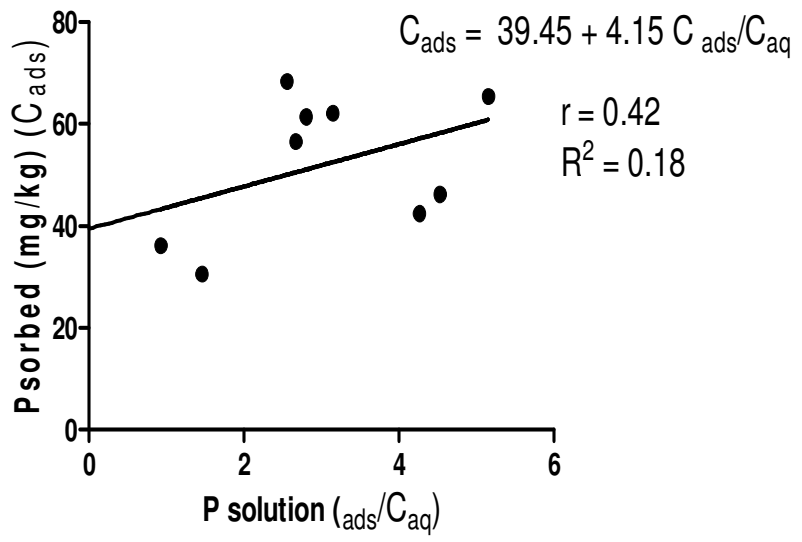

(a) Inland depression

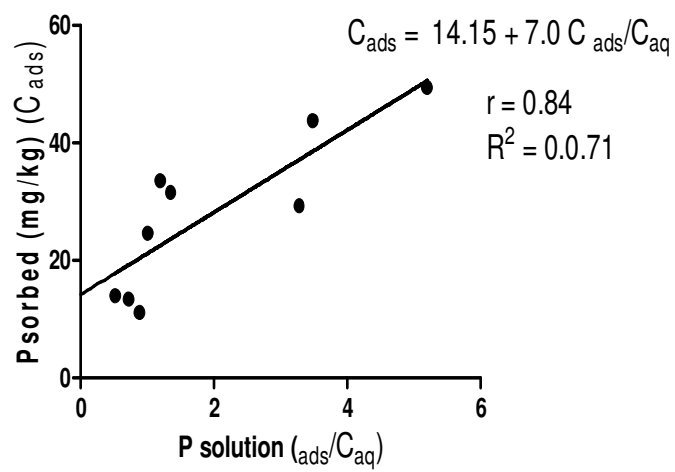

(b) Floodplain 


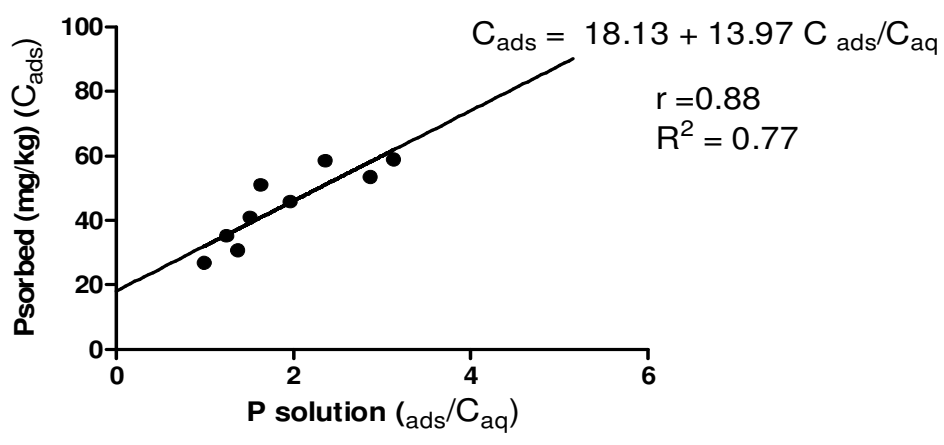

(c) Coastal swamp soil

Fig. 1: After 24 hours of equilibrium concentration (incubation)
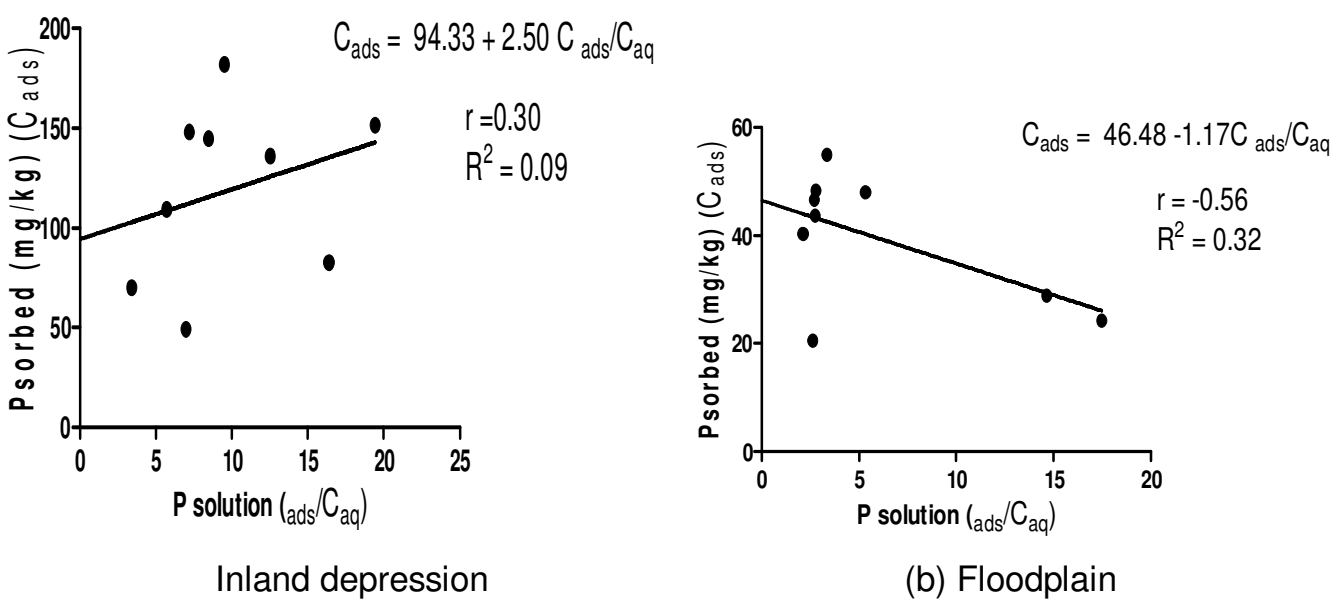

(b) Floodplain

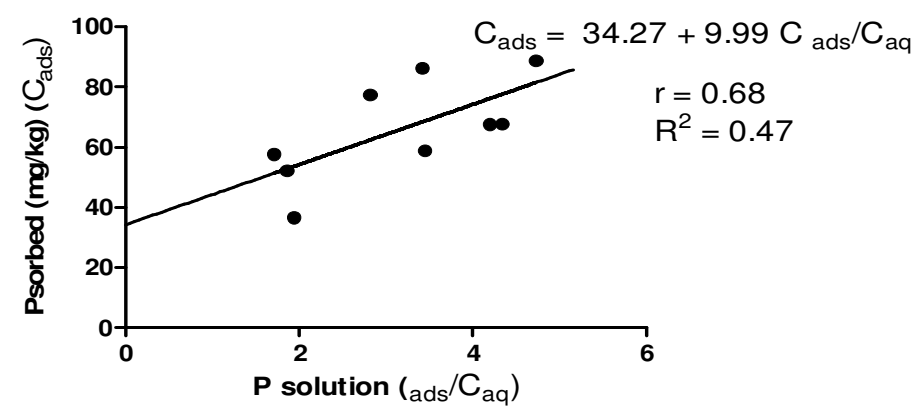

(a) Coastal swamp soil

Fig. 2: After 168 hours of equilibrium concentration (incubation) 
Table 1: Langmuir constants and linear equation for phosphorus adsorption in the study area

\begin{tabular}{lllllll}
\hline $\begin{array}{l}\text { Wetland } \\
\text { Type }\end{array}$ & $\begin{array}{l}\text { Incubation } \\
\text { Period } \\
\text { (hours) }\end{array}$ & $\begin{array}{l}\text { Maximum } \\
\text { adsorption } \\
\left(\mathrm{mgkg}^{-1}\right)\end{array}$ & $\begin{array}{l}\text { Bonding } \\
\begin{array}{l}\text { Energy } \\
\left(\mathrm{Lmg}^{-1}\right)\end{array}\end{array}$ & Equation & $\mathrm{R}$ & $\begin{array}{l}\text { Maximum buffering } \\
\text { capacity }\end{array}$ \\
\hline Inland & 24 & 0.24 & 0.1056 & $\mathrm{C} / \mathrm{S}=4.15 \mathrm{C}+39.45$ & 0.42 & 0.025 \\
depression & 168 & 0.40 & 0.0265 & $\mathrm{C} / \mathrm{S}=2.50 \mathrm{C}+94.33$ & 0.30 & 0.011 \\
& Mean & 0.32 & 0.066 & & & 0.018 \\
Floodplain & 24 & 0.14 & 0.5048 & $\mathrm{C} / \mathrm{S}=7.001 \mathrm{C}+14.15$ & 0.84 & 0.071 \\
& 168 & 0.86 & 0.0250 & $\mathrm{C} / \mathrm{S}=1.167 \mathrm{C}-46.48$ & -0.56 & 0.022 \\
& Mean & 0.50 & 0.265 & & & 0.047 \\
Coastal & 24 & 0.07 & 0.7880 & $\mathrm{C} / \mathrm{S}=13.97 \mathrm{C}+18.13$ & 0.88 & 0.055 \\
Swamp & 168 & 0.10 & 0.2918 & $\mathrm{C} / \mathrm{S}=9.99 \mathrm{C}+34.27$ & 0.68 & 0.029 \\
& Mean & 0.009 & 0.540 & & & 0.042
\end{tabular}

\section{CONCLUSION}

The study revealed that floodplain soils had the highest mean phosphate adsorption capacity, followed by soils of inland depression while coastal swamp soils had the least. The trend was as follow: floodplain soils > soils of inland depression > coastal swamp soils. Coastal swamp soils had the highest bonding energy, followed by floodplain soils while soils of inland depression had the least. The trend was as follow: coastal swamp soils > floodplain soils $>$ soils of inland depression. Floodplain soils had the highest maximum buffering capacity, followed by coastal swamp soil while soils of inland depression had the least. The trend was as follow: floodplain soils $>$ coastal swamp soils $>$ soils of inland depression. Hence, the three wetland soil types were not the same in $\mathrm{P}$ sorption capacity, bonding energy and buffering capacity.

\section{REFERENCES}

Akamigbo FOR (1984). The accuracy of filed texture in a humid tropical environment. Soil Survey and Land Evaluation 493:63-70.

Anderson $\mathrm{R}$ and $\mathrm{Wu} Y$ (2001). Phosphorus quantityintensity relationships and agronomic measures of $P$ in surface layers of soil from a long-term slurry experiment. Chemosphere. 42: 161-170.

Arai Y, Livi KJT and Sparks DL (2005). Phosphate reactivity in long-term poultry litter-amended southern delaware sandy soils, Soil Sci. Soc. Am. J., 69, 616- 629

Arai $Y$ and Livi K.J (2013). Underassessed phosphorus fixation mechanisms in soil sand fraction, Geoderma, 192, 422-429, 2013.

Ayodele OJ and Agboola AA (1981). Evaluation of Phosporus Fixing Capacity of Tropical Savannah Soils of Western Nigeria. Soil Sci. Soc. Am. J. 44: 462- 464.

Borling K (2003). Phosphorus Sorption, Accumulation and Leaching. Ph.D Thesis, Swedish University of Agricultural Sciences, Uppsala
Cade-Menun BJ (2005). Characterizing phosphorus in environmental and agricultural samples by $31 \mathrm{P}$ nuclear magnetic resonance spectroscopy, Talanta, 66, 359-371

Del-Bubba M, Arias CA and Brix H (2003). Phosphorus adsorption maximum of sands for use as media in sub-surface flow constructed reed beds as measured by the Langmuir isotherm. Water Res., 37: 3390-3400.

Enwezor WO, Udo EJ, Usoro NJ, Ayotade KA.., Adepetu JA. Chude VO. and Udegbe Cl (1989). Fertilizer Use and Management Practices for Crops in Nigeria Series 2. Federal Ministry of Agriculture, Water Resources and Rural Development, Lagos 18

Eshett ET, Omoeti JAI. and Juo ASR (1990) PhysicoChemical, Morphological and Clay Mineralogical Properties of Soils overlay Basement Complex Rocks in Ogoja, Northern Cross River State of Nigeria. Soil Science and Plant Nutrition 36(2): 203214.

Ho YS, Porter JF and Mckay G (2002). Equilibrium isotherm studies for the sorption of divalent metal ions onto peat. Copper, nickel and lead single component systems. Water Air Soil Pollut., 141: 133.

Hunt JF, Ohno T, He Z, Honeycutt CW and Dail DB (2007). Inhibition of phosphorus sorption to goethite, gibbsite, and kaolin by fresh and decomposed organic matter. Biol. Fert. Soil 44, 277288.

Khan ZH, Mazumder AR, Hussain MS And Saheed SM (1997). Chemical and Mineralogical Properties of Some Benchmark Soils in the Floodplains of Bangladesh. Journal of Indian Society of Soil Science 45: 362-369.

Ibia TO (2005). Forms and Contents of Iron and Aluminium in Inland flood plans of Southeastern Nigeria. Agron. Afr. XVII (3): 163-253.

Mehadi AA and Taylor RW (1988). Phosphate adsorption by two highly weathered soils. Soil Science Society of America Journal ; 52:627-632 1988.

Mckeaque JA, Brydon JE and Miles NM. (1971). 
Differentiation of forms of extractable iron and aluminum in soils. Soil Sci. Soc. Am. Proc. 35:303306.

Nelson DN and Sommers LE (1982). Total Carbon, Organic Carbon and Matter, In: methods of soil analysis part 2 (page A. D., Miller and D.K.M. Kenney). American Society of Agronomy, pp. 538579.

Nsor ME (2001). Fertility indices and Management of Mangrove Soils for Sustainable Food Crop Production. Paper Presented at the 27th Annual Conference of SSSN, University of Calabar, Calabar, Cross River State, Nov. 5-9

Ojanuga AG, Lekwa G and Okusami TA (2003). Distribution, Classification and Potentials of Wetland Soils of Nigeria. Monograph No. 2, 2nd Edi., Soil Science Society of Nigeria.

Petters SW, Usoro EJ, Udo EJ, Obot UW and Okpon SN (1989). Akwa Ibom State Physical Background, Soils, Land Use and Ecological Problems. Technical report of taskforce on soils and land use Govt. printer, Uyo pp. 602.

Rehman O, Ranjha AM, Saleem SM and Khan AA (2005). Phosphorus requirement of whet using modified Freudhih model in Sultanpur (Pakistan) Soil Series. Int. J. Agric. Biol. 7: 747

Reddy KR, Kadlec RH, Flaig E and Gale PM (1999). Phosphorus Assimilation in Streams and wetlands. A review Crit. Rev. Environ. Sci. Techno. 29:83-146

Reddy KR and Delaune RD (2005). Biogeochemistry of Wetlands. CRC Press, BocaRaton, FL (In Press)

Rhue RD and Harris WG (1999). Phosphorus Sorption/desorption Reaction in Soils and Sediments. In: Phosphorus Biochemistry in Subtropical Ecosystems, edited by Reddy KR, O'Connor GA and Schelske CL. Lewis Publishers, Boca Raton, pp. 187-206
Rick AR and Arai Y (2011). Role of natural nanoparticles in phosphorus transport processes in ultisols Soil Sci. Soc. Am. J., 75, 335-347

Rubæk GH, Guggenberger G, Zech W and Christensen BT (1999). Organic phosphorus in soil size separates characterized by phosphorus-31 nuclear magnetic resonance and resin extraction, Soil Sci. Soc. Am. J., 63, 1123-1132.

Sposito G (1989). The Chemistry of Soils. Oxford University Press. Inc., PP. 127147

Solomon D and Lehmann J (2000). Loss of phosphorus from soil in semi-arid northern Tanzania as a result of cropping: evidence from sequential extraction and 31P-NMR spectroscopy, Eur. J. Soil Sci., 51, 699708

Solomon D, Lehmann J, Mamo T, Fritzsche F and Zech W (2002). Phosphorus forms and dynamics as influenced by land use changes in the sub-humid Ethiopian highlands, Geoderma, 105, 21-48

Turner BL, Cade-Menun BJ, Condron LM and Newman $S$ (2005). Extraction of soil organic phosphorus, Talanta, 66, 294-306

Udo EJ (1980). Profile Distribution of Iron sesquioxides Contents in Selected Nigerian soils. Journal of Agric Science. Cambridge 95:191-198.

University of Uyo (Uniuyo) Consults Limited (2001). Soil Survey Report. Ministry of Agriculture, Uyo, Akwa Ibom State.

Uzoho BU (2014). Sesquioxides Distribution of Soils of Contrasting Land Units in Egbema, Southeastern, Nigeria Journal of Environment and Earth Science. Vol. 4, No.6, 101-109pp.

Yuji A and Sparks DL (2001). ATR - FTIR Spectroscopic Investigation on Phosphate adsorption mechanisms of the ferrihydrite-water interface. Journal of Colloid and Interface Science, 241 (2): $317-326$ 